\title{
The Effect of Ca Content on the Formation Behavior of Inclusions in the Heat Affected Zone of Thick High-Strength Low-Alloy Steel Plates after Large Heat Input Weldings
}

\author{
Yinhui Zhang ${ }^{1}{ }^{\oplus}$, Jian Yang ${ }^{1, *}$, Longyun $X u^{1}{ }^{1}$, Yunlong Qiu ${ }^{2}$, Guoguang Cheng ${ }^{3}$, Meiyi Yao ${ }^{4}$ \\ and Jianxin Dong ${ }^{5}$ \\ 1 State Key Laboratory of Advanced Special Steel, School of Materials Science and Engineering, \\ Shanghai University, Shanghai 200444, China; yinhuizhang@shu.edu.cn (Y.Z.); xulongyun@shu.edu.cn (L.X.) \\ 2 Zhongxing Energy Equipment Co., LTD, Haimen 226126, China; dongyh1115@zxnyzb.com \\ 3 State Key Laboratory of Advanced Metallurgy, University of Science and Technology Beijing, Beijing 100083, \\ China; chengguoguang@metall.ustb.edu.cn \\ 4 Institute of Materials, Shanghai University, Shanghai 200072, China; yaomeiyi@shu.edu.cn \\ 5 School of Materials Science and Engineering, University of Science and Technology Beijing, Beijing 100083, \\ China; jxdong@ustb.edu.cn \\ * Correspondence: yang_jian@t.shu.edu.cn; Tel.: +86-021-6613-6580
}

Received: 31 October 2019; Accepted: 5 December 2019; Published: 7 December 2019

\begin{abstract}
Ca deoxidation has been acknowledged recently as an effective oxide metallurgy technology that improves the toughness of the heat affected zone (HAZ) in high-strength low-alloy (HSLA) steel plates after large heat input welding. This paper describes the effect of Ca concentrations on the formation behavior of the non-metallic inclusions in the HAZs of a series of thick HSLA steel plates after large heat input welding at $400 \mathrm{~kJ} \mathrm{~cm}^{-1}$. The quantitative statistics on the inclusions show that the $\mathrm{Ca}$ addition significantly decreases the quantity of the pure MnS sulfide, but increases that of the complex oxysulfide. The pure MnS sulfide precipitates below the solidus temperature, while the complex oxysulfide forms in the molten liquid, leading to the core (oxide) and shell (sulfide) structure. The Ca addition proportionally improves the HAZ toughness of these thick HSLA steel plates, primarily owing to the positive effect of the complex oxysulfides on the refinement of the HAZ microstructure.
\end{abstract}

Keywords: HSLA steels; inclusions; calcium deoxidation; heat affected zone; large heat input welding

\section{Introduction}

Marine trade is growing rapidly in a global scale and increases the demands for super-large container ships [1]. Building these large steel structures requires thick steel plates, particularly those with a thickness larger than $50 \mathrm{~mm}$ [2]. In order to reduce the costs and increase the manufacturing efficiency, large heat input welding is welcome by the shipbuilding industry [3]. Unfortunately, the employment of this effective welding technology will deteriorate the microstructure of the heat affected zone (HAZ) and reduce the strength and toughness [4]. This will induce brittle fractures in a cold service environment, giving rise to great risks for the container ships [5]. Therefore, an emergent demand is addressed from the shipbuilding industry to improve the HAZ toughness of these thick steel plates at low temperatures after large heat input welding.

Oxide metallurgy technology is popularly used for these thick steel plates with large heat input welding, owing to its positive effects on the refinement of the HAZ microstructure and thus the 
improvement in the HAZ toughness at low temperatures [6]. This technology has been developed for several decades, since the first use of TiN particles to prevent the growth of prior austenite grains in the HAZ at 1970s [7,8]. In the 1990s, the deoxidation of Ti was developed, by which the thermal stable $\mathrm{Ti}_{2} \mathrm{O}_{3}$ particles could significantly nucleate the intragranular acicular ferrite (IAF), a typical fine and inter-locking HAZ microstructure [9]. Nowadays, numerous efforts have been paid to develop this oxide metallurgy technology by use of a strong deoxidant, such as Mg, Zr, and REM [10-13]. Xu et al. have reported that the deoxidation of $\mathrm{Mg}$ can form a uniform dispersion of fine $\mathrm{MgO}-\mathrm{MnS}$ complex inclusions, leading to the refinement of prior austenite grains and the nucleation of IAFs [14,15]. Wang et al. have recognized that a few additions of $\mathrm{Zr}$ can form $\mathrm{ZrO}_{2}$ complex inclusions wrapped by MnS sulfide, which can accelerate the nucleation of IAFs as well [16]. These advanced technologies have successfully improved the toughness of the HAZ in EH36 shipbuilding steels after large heat input welding at $400 \mathrm{~kJ} \mathrm{~cm}^{-1}[17,18]$.

Moreover, the deoxidation of $\mathrm{Ca}$, another strong deoxidant, was also developed in recent years, with an improvement in the toughness of the HAZ at low temperatures $[13,19]$. Ca addition has been widely used in steelmaking, for the purposes of forming $\mathrm{Al}_{2} \mathrm{O}_{3}-\mathrm{CaO}$ complex inclusion rather than a single $\mathrm{Al}_{2} \mathrm{O}_{3}$ oxide to prevent nozzle clogging and modifying the $\mathrm{MnS}$ sulfide and $\mathrm{Mg}-\mathrm{Al}$ spinel to improve the impact toughness of thick steel plates [20]. However, very limited papers regarding the positive effect of Ca oxide metallurgy on the large heat input welding properties of thick steel plates have been published, apart from a few technical reports from several steel corporations [21,22]. As a result, the mechanism of the $\mathrm{Ca}$ addition on the microstructure of the HAZ has not been investigated thoroughly, including the formation mechanism of the Ca-bearing inclusions.

Therefore, the objective of the present research is to investigate the effect of Ca concentrations on the formation behavior of the non-metallic inclusions in a series of high-strength low-alloy (HSLA) steel plates with a thickness of $50 \mathrm{~mm}$ after large heat input welding at $400 \mathrm{~kJ} \mathrm{~cm}^{-1}$. The inclusions were quantitatively analyzed within a relatively large area of each experimental steel, in order to increase the statistical precision. Computational thermodynamic calculations were also carried out to aid in the understanding of the formation sequence of different inclusions. Based on these experimental and calculated methods, the effect of Ca concentrations on the formation mechanism of the non-metallic inclusions in the HAZ of these HSLA steels is clarified. The positive effects of the inclusions on the refinement of the HAZ microstructure and the enhancement of the HAZ toughness are also explained. The generated data and understanding will be helpful to the future study of the microstructure and toughness of the HAZ in these HSLA steels with Ca deoxidation after large heat input welding.

\section{Materials and Methods}

A series of HSLA steels were melted in a $50 \mathrm{~kg}$ vacuum induction furnace (Jinzhou Maite Vacuum Equipment Co., Ltd., Jinzhou, China) and cast into ingots with a size of $120 \times 180 \times 240 \mathrm{~mm}^{3}$. Proper amounts of deoxidants, comprising $\mathrm{Mn}, \mathrm{Si}, \mathrm{Ti}, \mathrm{Al}$, and $\mathrm{Ca}$, were added to reduce the $\mathrm{O}$ content and to obtain the target compositions. Table 1 shows the compositions of these steels determined by chemical methods (e.g., inductively coupled plasma atomic emission spectrometry), and they are named according to their Ca concentrations. Subsequently, these steel ingots were hot-rolled into thick steel plates with the thermo-mechanical control process (TMCP). The start rolling was carried out at a temperature above $930{ }^{\circ} \mathrm{C}$, with a reduction ratio larger than $30 \%$, followed by the finish rolling at about $800{ }^{\circ} \mathrm{C}$, with a reduction ratio larger than $30 \%$ as well. Ultimately, these steel plates with a final thickness of $50 \mathrm{~mm}$ were cooled from 750 to $400{ }^{\circ} \mathrm{C}$ at a cooling rate of $10^{\circ} \mathrm{C} \mathrm{s}^{-1}$. 
Table 1. Measured chemical compositions of the HSLA steels with different Ca concentrations (wt \%).

\begin{tabular}{ccccccccccc}
\hline Steels & $\mathbf{C}$ & $\mathbf{S i}$ & $\mathbf{M n}$ & $\mathbf{P}$ & $\mathbf{S}$ & $\mathbf{A l}$ & $\mathbf{N}$ & $\mathbf{T i}$ & $\mathbf{O}$ & $\mathbf{C a}$ \\
\hline $2 \mathrm{Ca}$ & 0.08 & 0.2 & 1.5 & 0.006 & 0.004 & 0.001 & 0.0034 & 0.0093 & 0.0018 & 0.0002 \\
$7 \mathrm{Ca}$ & 0.08 & 0.2 & 1.5 & 0.007 & 0.006 & 0.003 & 0.0032 & 0.012 & 0.0022 & 0.0007 \\
$11 \mathrm{Ca}$ & 0.08 & 0.2 & 1.5 & 0.009 & 0.007 & 0.004 & 0.0048 & 0.013 & 0.0019 & 0.0011 \\
$18 \mathrm{Ca}$ & 0.08 & 0.2 & 1.5 & 0.007 & 0.004 & 0.006 & 0.0044 & 0.0096 & 0.0012 & 0.0018 \\
$25 \mathrm{Ca}$ & 0.08 & 0.2 & 1.5 & 0.007 & 0.005 & 0.007 & 0.0037 & 0.011 & 0.0019 & 0.0025 \\
\hline
\end{tabular}

Specimens with a size of $11 \times 11 \times 71 \mathrm{~mm}^{3}$ for large heat input welding simulations were machined from the square regions with distances of a $1 / 4$ width and a $1 / 4$ thickness away from the edge of the TMCP steel plates. These weld simulations were carried out on a Gleeble 3800 thermal-mechanical physical simulator (Dynamic Systems Inc., Poestenkill, NY, USA) to simulate an electrogas arc welding with the heat input of $400 \mathrm{~kJ} \mathrm{~cm}^{-1}$. The welding temperature was controlled by a thermocouple wire-percussion-welded at the middle part of the specimens. The peak temperature was determined to be $1400{ }^{\circ} \mathrm{C}$, with a holding time of $3 \mathrm{~s}$ during the thermal cycle in the HAZ. Subsequently, the specimens were cooled to $800{ }^{\circ} \mathrm{C}$ at a rate of $3.4^{\circ} \mathrm{C} \mathrm{s}^{-1}$ and then cooled to $500^{\circ} \mathrm{C}$ at a rate of $0.8{ }^{\circ} \mathrm{C} \mathrm{s}^{-1}$. After welding simulations, the specimens were cut into $10 \times 10 \times 55 \mathrm{~mm}^{3}$ with the notch tip in the middle part of the simulated HAZ, followed by the Charpy impact tests at $-20^{\circ} \mathrm{C}$.

After the Charpy impact tests, the HAZs of these weld simulated specimens were cut for microstructural analyses. The HAZ specimens were ground and polished standardly, up to a final polishing with colloidal silica $(0.02 \mu \mathrm{m})$, without etching. The morphology and composition of the non-metallic inclusions were characterized by use of an EVO 18 scanning electron microscope (SEM, Carl Zeiss AG, Oberkochen, Germany), equipped with an energy dispersive spectrometer (EDS) and an automatic EDS software Aztec Feature (Oxford Instruments, Ann Arbor, MI, USA).

The formation behavior of the non-metallic inclusions in these HSLA steels were simulated by the use of the thermodynamic calculation software FactSage (Thermfact/CRCT, Montreal, QC, Canada and GTT-Technologies, Aachen, Germany) with the database of FSstel and FToxid (version 7.3). The simulations were performed under the equilibrium conditions, with a temperature range between 600 and $1800{ }^{\circ} \mathrm{C}$ and a temperature step of $2{ }^{\circ} \mathrm{C}$. The chemical compositions listed in Table 1 were used for these thermodynamic simulations.

\section{Results}

\subsection{Thermodynamic Calculations}

In order to evaluate the effect of Ca additions on the formation of the non-metallic inclusions, the quantity of different phases in the thick HSLA steel plates with different Ca concentrations was calculated by FactSage software under the equilibrium condition. Figure 1 shows the mass fractions of different phases in these HSLA steels as a function of temperature and the calculated compositions of the slag phase are shown in Figure 2. The slag phase was predicted to solidify in the molten liquid region of the $2 \mathrm{Ca}$ steel, and it was enriched in $\mathrm{Ti}_{2} \mathrm{O}_{3}, \mathrm{TiO}_{2}$, and $\mathrm{CaO}$ (Figures $1 \mathrm{a}$ and 2a). In contrast, $\mathrm{MnS}$, $\mathrm{TiN}$, and $\mathrm{Al}_{2} \mathrm{O}_{3}$ particles were predicted to form at relatively low temperatures after the liquid-solid solidification completely finished. Therefore, the formation sequence of the non-metallic inclusions in the 2Ca steel was described as slag $\rightarrow \mathrm{MnS} \rightarrow \mathrm{TiN} \rightarrow \mathrm{Al}_{2} \mathrm{O}_{3}$. 


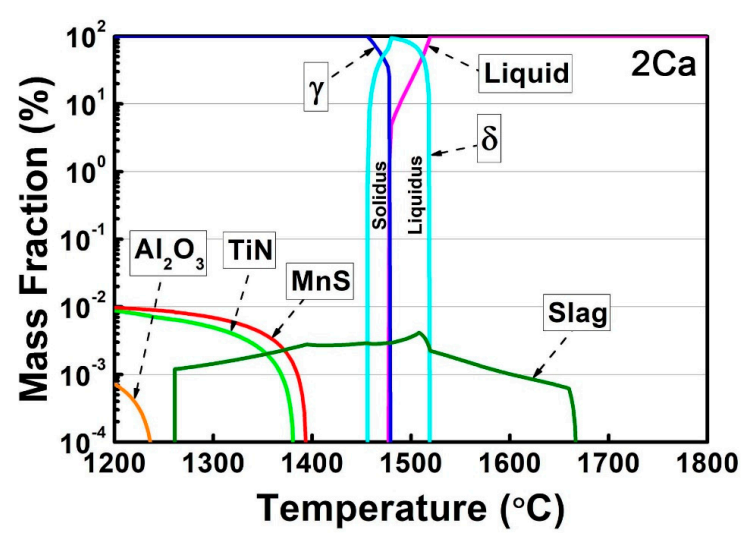

(a)

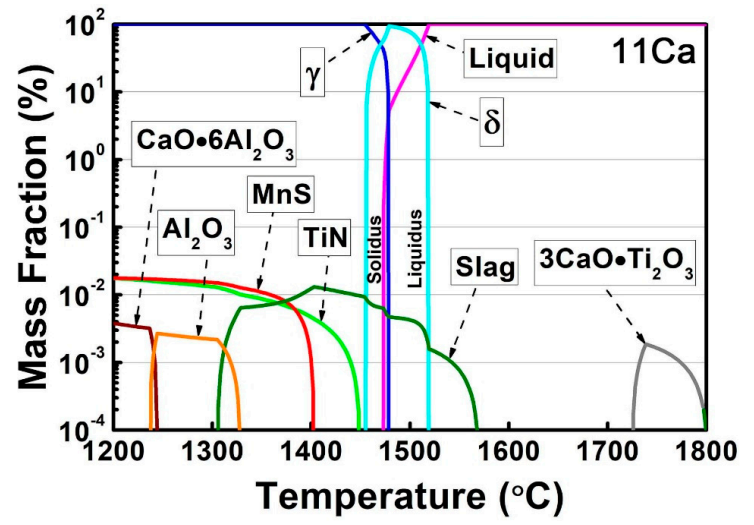

(c)

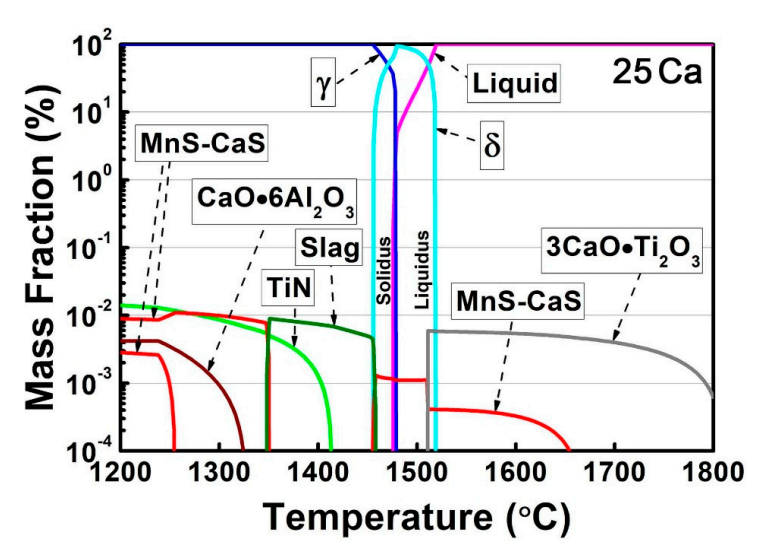

(e)

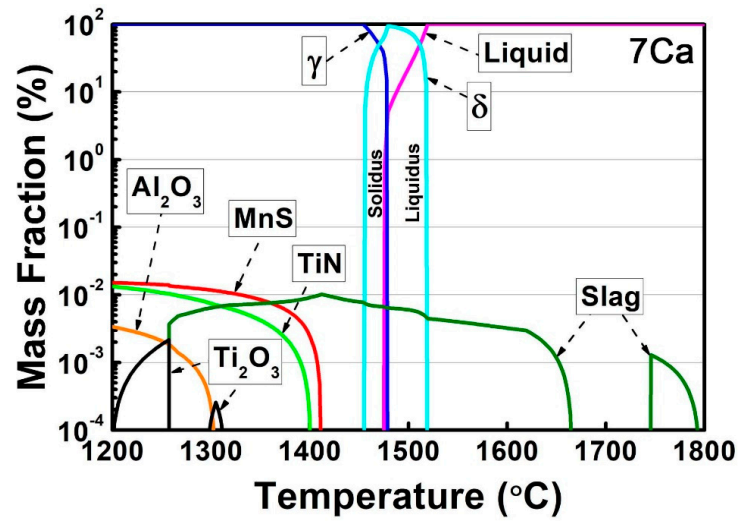

(b)

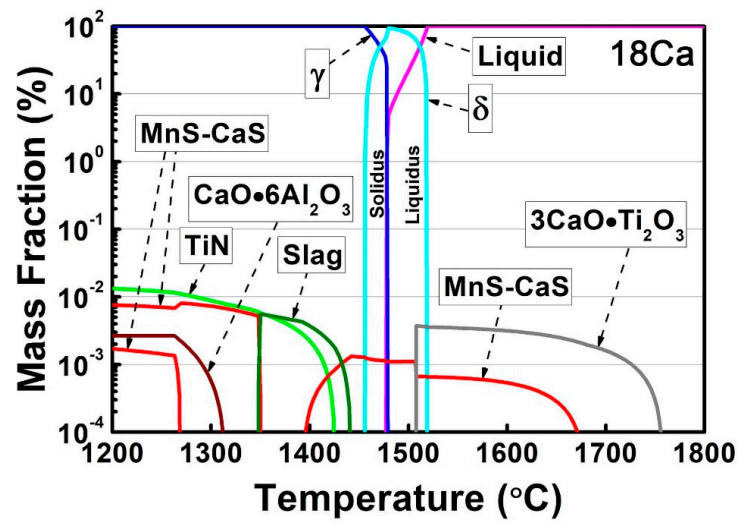

(d)

Figure 1. Mass fractions of different phases in the HSLA steels: (a) 2Ca, (b) 7Ca, (c) 11Ca, (d) 18Ca, and (e) $25 \mathrm{Ca}$ as a function of temperature by FactSage software under the equilibrium condition. 


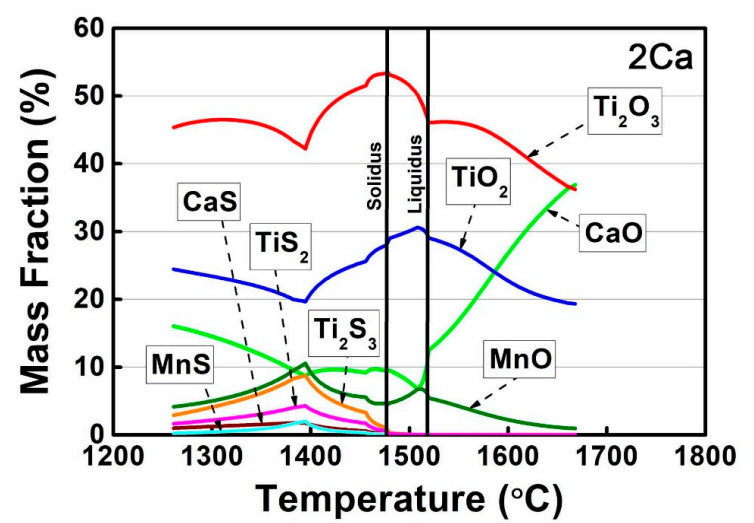

(a)

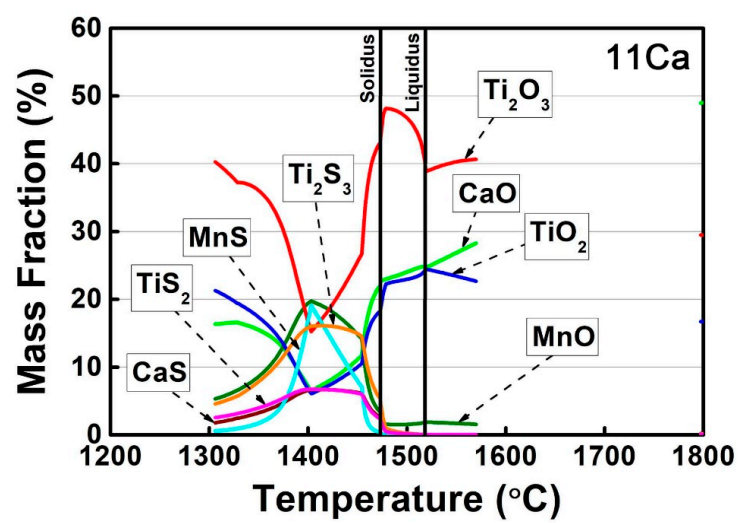

(b)

Figure 2. Compositions of the slag phase in the HSLA steels (a) 2Ca and (b) 11Ca as a function of temperature by FactSage software under the equilibrium condition.

Although the phase equilibrium in the 7Ca steel was similar to that in the 2Ca steel, the new formation of $\mathrm{Ti}_{2} \mathrm{O}_{3}$ oxide was predicted at temperatures below $1315^{\circ} \mathrm{C}$ (Figure 1b). Moreover, the formation temperature and quantity of the slag phase as well as the $\mathrm{MnS}, \mathrm{TiN}$, and $\mathrm{Al}_{2} \mathrm{O}_{3}$ particles increased as the Ca content increased to $7 \mathrm{ppm}$. Accordingly, the formation sequence of the different non-metallic inclusions in the 7Ca steel was altered to be slag $\rightarrow \mathrm{MnS} \rightarrow \mathrm{TiN} \rightarrow \mathrm{Ti}_{2} \mathrm{O}_{3} \rightarrow \mathrm{Al}_{2} \mathrm{O}_{3}$.

By comparison with the $7 \mathrm{Ca}$ steel, a new $3 \mathrm{CaO} \cdot \mathrm{Ti}_{2} \mathrm{O}_{3}$ complex oxide formed instead of the slag phase at temperatures above $1700{ }^{\circ} \mathrm{C}$ in the $11 \mathrm{Ca}$ steel, while the formation temperature of the slag phase decreased to $1570{ }^{\circ} \mathrm{C}$ (Figure 1c). Figure $2 \mathrm{~b}$ demonstrates that the slag phase was also enriched in $\mathrm{Ti}_{2} \mathrm{O}_{3}, \mathrm{TiO}_{2}$, and $\mathrm{CaO}$, whereas the content of sulfide (MnS) was slightly increased. In the solid region, the precipitation temperature of the TiN particle significantly increased to $1450{ }^{\circ} \mathrm{C}$, the highest formation temperature of the TiN nitride in this steel system, corresponding to the highest Ti and $\mathrm{N}$ concentrations (Table 1). In addition, a new $\mathrm{CaO} \cdot 6 \mathrm{Al}_{2} \mathrm{O}_{3}$ complex oxide was predicted at the low temperature region, so the new formation sequence of the non-metallic inclusions could be described as $3 \mathrm{CaO} \cdot \mathrm{Ti}_{2} \mathrm{O}_{3} \rightarrow$ slag $\rightarrow \mathrm{TiN} \rightarrow \mathrm{MnS} \rightarrow \mathrm{Al}_{2} \mathrm{O}_{3} \rightarrow \mathrm{CaO} \cdot 6 \mathrm{Al}_{2} \mathrm{O}_{3}$.

By increasing the Ca content to $18 \mathrm{ppm}$, the formation temperature range and quantity of the $3 \mathrm{CaO} \cdot \mathrm{Ti}_{2} \mathrm{O}_{3}$ complex oxide significantly increased in the molten liquid region, as well as the MnS and CaS complex sulfide (Figure 1d). These MnS-CaS complex sulfide formed two phase curves in the solid region, because of the existence of the miscibility gap. On the contrary, the formation temperature range of the slag phase was obviously narrowed, with the formation temperature below the solidus temperature. Thermodynamic calculations demonstrated that this slag phase was enriched in $\mathrm{CaS}$ and $\mathrm{MnS}$, different from that in the $2 \mathrm{Ca}, 7 \mathrm{Ca}$, and $11 \mathrm{Ca}$ steels. Therefore, the formation sequence of the inclusions in the $18 \mathrm{Ca}$ steel was significantly changed into $3 \mathrm{CaO} \cdot \mathrm{Ti}_{2} \mathrm{O}_{3} \rightarrow \mathrm{MnS}-\mathrm{CaS} \rightarrow$ slag $\rightarrow \mathrm{TiN} \rightarrow$ $\mathrm{CaO} \cdot 6 \mathrm{Al}_{2} \mathrm{O}_{3}$.

The non-metallic inclusions in the $25 \mathrm{Ca}$ steel had a similar formation sequence to that in the $18 \mathrm{Ca}$ steel, as shown in Figure 1e. However, the formation temperature and quantity of the $3 \mathrm{CaO} \cdot \mathrm{Ti}_{2} \mathrm{O}_{3}$ particle significantly increased, due to the highest $\mathrm{Ca}$ content in this steel system. Moreover, the precipitation temperature of the TiN nitride decreased continuously after it reached the maximum value in the 11Ca steel.

\subsection{Number Densities, Sizes, and Compositions of Inclusions}

The quantity and size of the non-metallic inclusions in the HAZs of the thick HSLA steel plates were analyzed within a relatively large area $\left(>25 \mathrm{~mm}^{2}\right)$, with the effective statistics on the number of the inclusions larger than 1700 for each steel. Figure 3 shows the number density and size of the total non-metallic inclusions in the HAZs of these steel plates with different Ca concentrations. The 
number densities of the inclusions were approximately comparable, about 60-80 per $\mathrm{mm}^{2}$, except for the $7 \mathrm{Ca}$ steel with the highest value. The average inclusion sizes in the $2 \mathrm{Ca}, 7 \mathrm{Ca}$, and $11 \mathrm{Ca}$ steels were relatively small, but the sizes increased significantly to larger than $2.6 \mu \mathrm{m}$ in steels $18 \mathrm{Ca}$ and $25 \mathrm{Ca}$.

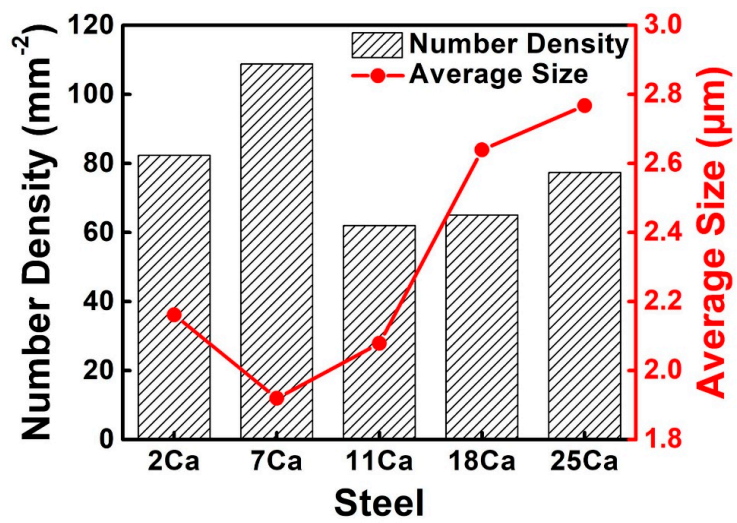

Figure 3. Number densities and sizes of the non-metallic inclusions in the HAZs of the thick HSLA steel plates with different Ca concentrations after large heat input welding at $400 \mathrm{~kJ} \mathrm{~cm}^{-1}$.

Figure 4 shows the size distribution of the total non-metallic inclusions in the HAZs of these steel plates with different $\mathrm{Ca}$ concentrations. Fine inclusions were formed in the $2 \mathrm{Ca}, 7 \mathrm{Ca}$, and $11 \mathrm{Ca}$ steels, particularly the inclusions with a size smaller than $2 \mu \mathrm{m}$, accounting for larger than $60 \%$. These inclusions were coarsened in the 18Ca and 25Ca steels, particularly the obvious increase in the proportion of the inclusions with the size larger than $3 \mu \mathrm{m}$.

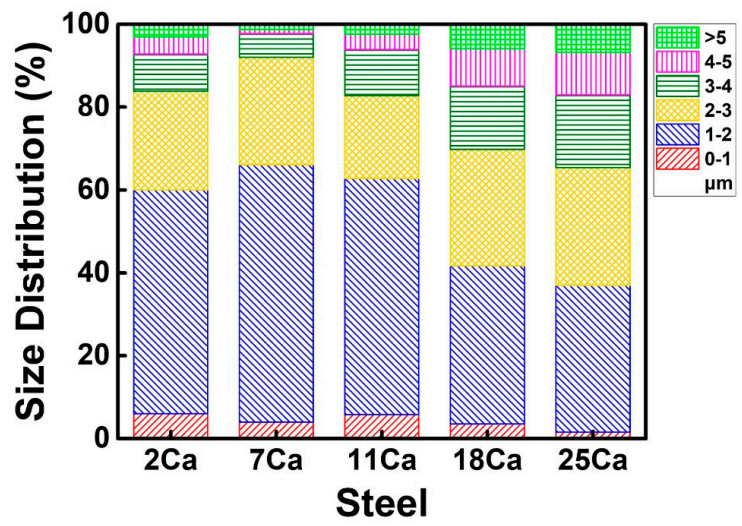

Figure 4. Size distributions of the non-metallic inclusions in the HAZs of the thick HSLA steel plates with different Ca concentrations after large heat input welding at $400 \mathrm{~kJ} \mathrm{~cm}^{-1}$.

Figure 5 shows the number density of each type of the non-metallic inclusions in the HAZs of these thick HSLA steel plates with different Ca concentrations. These inclusions were classified depending on their compositions analyzed by SEM-EDS. The number density of the MnS sulfide is overwhelmingly high in the $2 \mathrm{Ca}$ steel, followed by $\mathrm{MnS}-\mathrm{Al}_{2} \mathrm{O}_{3}-\mathrm{Ti}_{2} \mathrm{O}_{3}, \mathrm{MnS}-\mathrm{Ti}_{2} \mathrm{O}_{3}, \mathrm{Al}_{2} \mathrm{O}_{3}-\mathrm{Ti}_{2} \mathrm{O}_{3}$, and other complex inclusions (Figure 5a). The quantity of this pure MnS sulfide decreased in the 7Ca steel, but the quantity of the Ca-bearing inclusions increased instead, including $\mathrm{MnS}-\mathrm{Al}_{2} \mathrm{O}_{3}-\mathrm{CaO}_{-}-\mathrm{Ti}_{2} \mathrm{O}_{3}$, $\mathrm{Al}_{2} \mathrm{O}_{3}-\mathrm{CaO}-\mathrm{Ti}_{2} \mathrm{O}_{3}$, and $\mathrm{MnS}-\mathrm{CaS}$ complex inclusions (Figure 5b).

By comparison with the 2Ca and 7Ca steels, the number density of the pure MnS sulfide in the $11 \mathrm{Ca}$ steel was extremely low, but the quantity of the $\mathrm{MnS}-\mathrm{Al}_{2} \mathrm{O}_{3}-\mathrm{CaO}-\mathrm{Ti}_{2} \mathrm{O}_{3}$ complex oxysulfide had an obvious increase, reaching the largest proportion (Figure $5 \mathrm{c}$ ). In the $18 \mathrm{Ca}$ steel, the quantity of the MnS-CaS complex sulfide increased continuously, in spite of the relatively low amount of the pure $\mathrm{MnS}$ particle (Figure $5 \mathrm{~d}$ ). In addition, $\mathrm{CaS}$ was initially detected in the $\mathrm{MnS}-\mathrm{CaS}-\mathrm{Al}_{2} \mathrm{O}_{3}-\mathrm{CaO}_{-} \mathrm{Ti}_{2} \mathrm{O}_{3}$ complex oxysulfide with the largest quantity in this steel. Figure 5e shows that the number density 
of each type of the inclusions in the 25Ca steel was similar to that in the 18Ca steel. Apart from the oxide, sulfide, and oxysulfide, the quantities of the pure TiN and TiN-bearing complex inclusions were extremely low in this steel system.

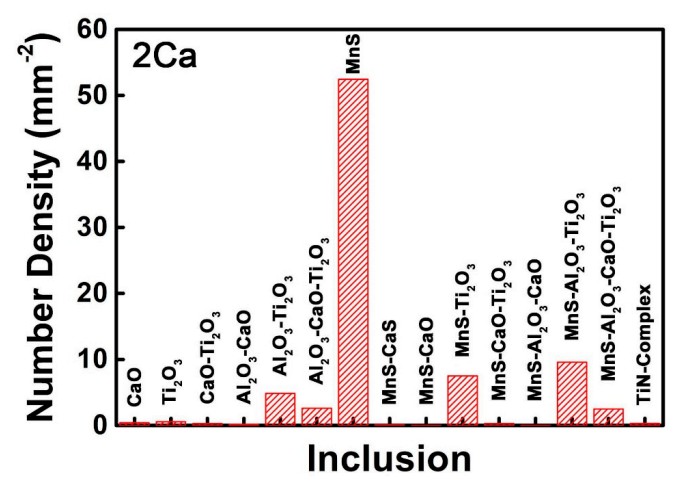

(a)

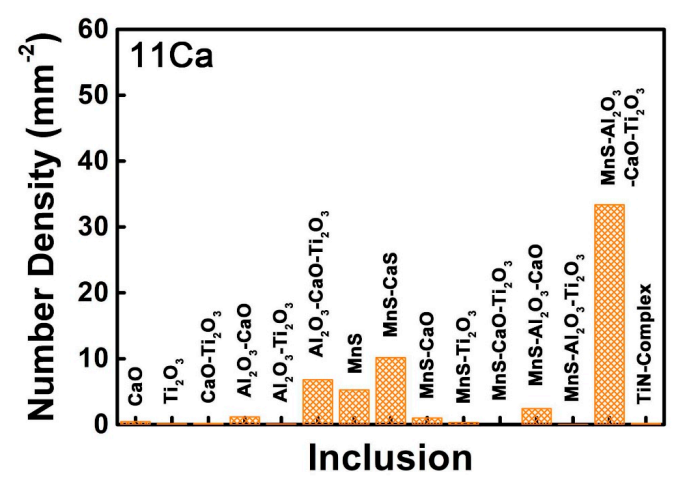

(c)

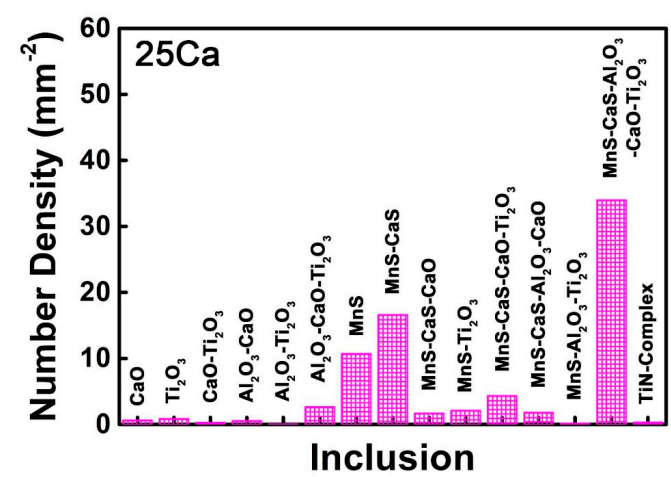

(e)

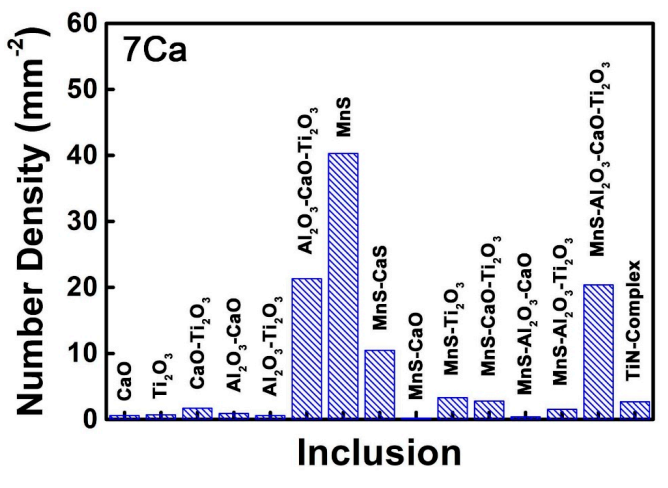

(b)

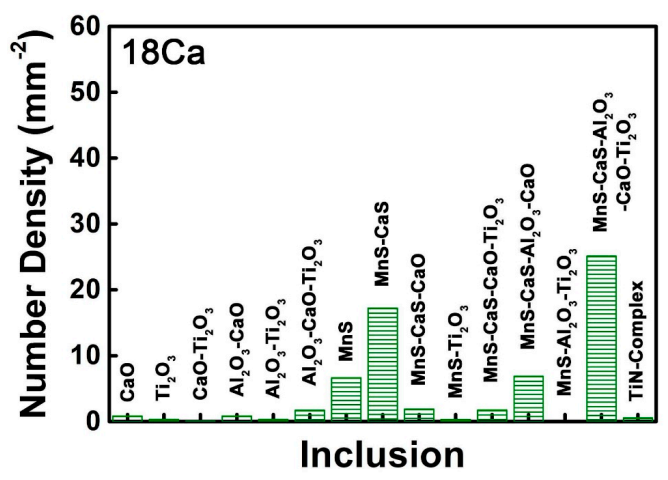

(d)

Figure 5. Number densities of each type of the non-metallic inclusions in the HAZs of the thick HSLA steel plates (a) 2Ca, (b) 7Ca, (c) 11Ca, (d) 18Ca, and (e) 25Ca after large heat input welding at $400 \mathrm{~kJ} \mathrm{~cm}^{-1}$.

Figure 6 shows the size of each type of the non-metallic inclusions in the HAZs of these thick HSLA steel plates with different Ca concentrations, in which the inclusions with the number density larger than $10 \mathrm{~mm}^{-2}$ are marked by circles. The average size of the pure MnS sulfide with the largest number density in the 2Ca steel was measured to be $1.7 \mu \mathrm{m}$, smaller than the average size of the total inclusions (Figure 6a). Figure $6 \mathrm{~b}$ shows that the average size of the most types of the non-metallic 
inclusions in the 7Ca steel had a decrease compared to the 2Ca steel, particularly the size of the MnS- $\mathrm{Al}_{2} \mathrm{O}_{3}-\mathrm{CaO}-\mathrm{Ti}_{2} \mathrm{O}_{3}$ and $\mathrm{Al}_{2} \mathrm{O}_{3}-\mathrm{CaO}-\mathrm{Ti}_{2} \mathrm{O}_{3}$ oxysulfides. In the $11 \mathrm{Ca}$ steel, the average size of the MnS- $\mathrm{Al}_{2} \mathrm{O}_{3}-\mathrm{CaO}-\mathrm{Ti}_{2} \mathrm{O}_{3}$ oxysulfide was measured to be $2.3 \mu \mathrm{m}$, and its higher proportion slightly increased the average size of the total inclusions (Figure 6c). When the Ca content was increased to 18 and $25 \mathrm{ppm}, \mathrm{CaS}$ sulfide formed and the average size of the CaS-bearing MnS- $\mathrm{CaS}-\mathrm{Al}_{2} \mathrm{O}_{3}-\mathrm{CaO}-\mathrm{Ti}_{2} \mathrm{O}_{3}$ oxysulfide increased to 3.3 and $3.4 \mu \mathrm{m}$, respectively (Figure $6 \mathrm{~d}, \mathrm{e}$ ), much larger than the size of the MnS- $\mathrm{Al}_{2} \mathrm{O}_{3}-\mathrm{CaO}-\mathrm{Ti}_{2} \mathrm{O}_{3}$ oxysulfide in the $7 \mathrm{Ca}$ and $11 \mathrm{Ca}$ steels.

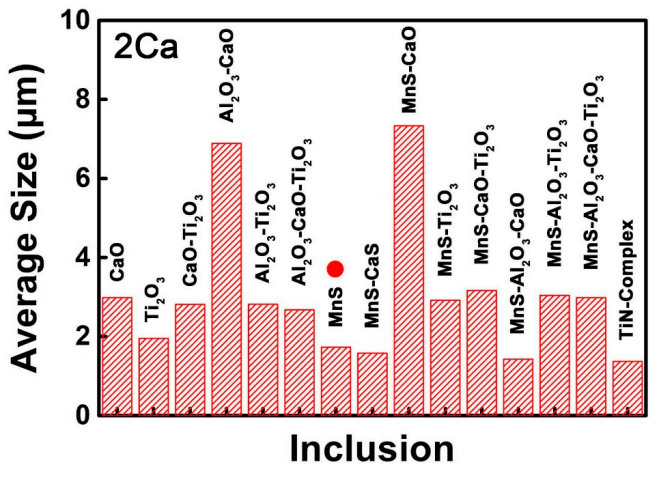

(a)

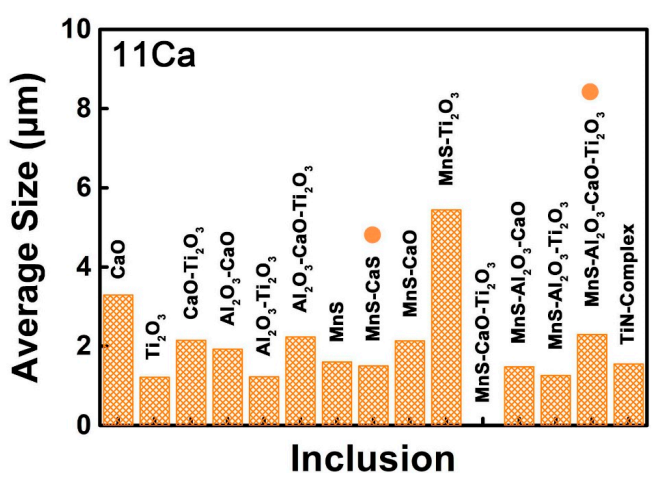

(c)

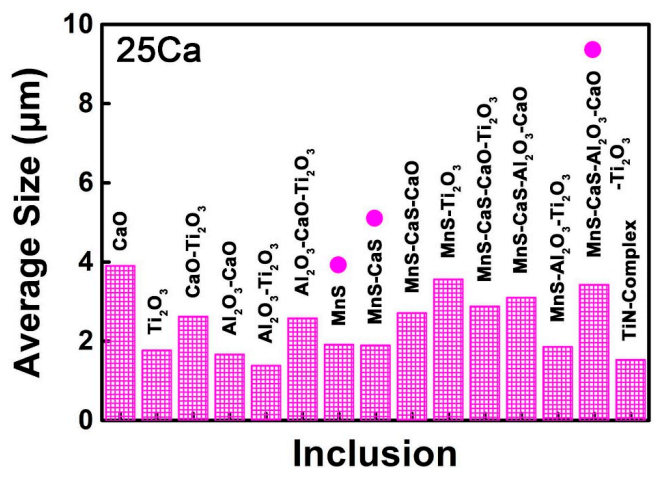

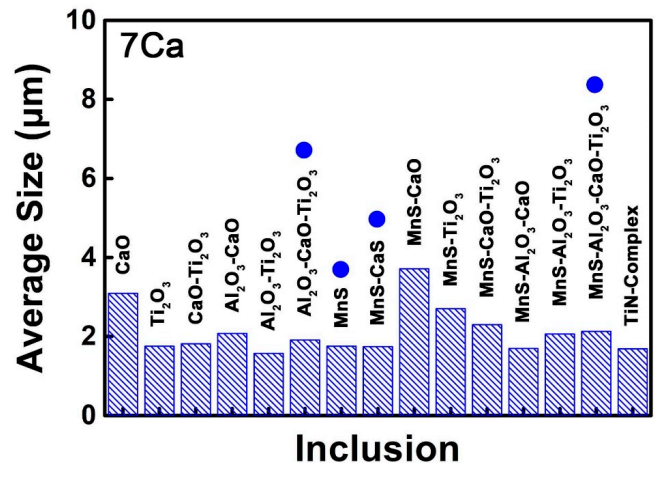

(b)

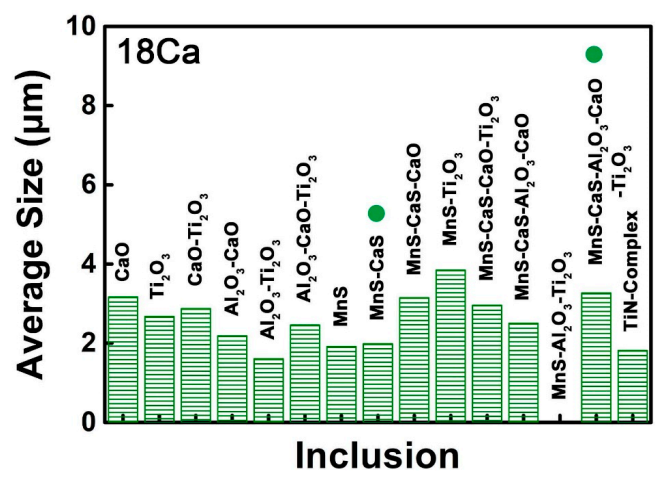

(d)

(e)

Figure 6. Sizes of each type of the non-metallic inclusions in the HAZs of the thick HSLA steel plates (a) $2 \mathrm{Ca},(\mathbf{b}) 7 \mathrm{Ca},(\mathbf{c}) 11 \mathrm{Ca}$, (d) $18 \mathrm{Ca}$, and (e) $25 \mathrm{Ca}$ after large heat input welding at $400 \mathrm{~kJ} \mathrm{~cm}^{-1}$.

Figure 7 shows the average compositions of the total non-metallic inclusions in the HAZs of these steel plates with different Ca concentrations, determined by SEM-EDS. The concentrations of $\mathrm{Mn}$ and $\mathrm{S}$ decreased and then increased as the $\mathrm{Ca}$ addition increased to these steels, corresponding 
well to the change in the quantity of pure sulfides (MnS and MnS-CaS) (Figure 5). In contrast to the change of the $\mathrm{Mn}$ and $\mathrm{S}$ concentrations, the concentrations of $\mathrm{Al}, \mathrm{Ca}$, Ti, and $\mathrm{O}$ increased and then decreased, indicating the alternation in the quantity of oxides. In addition, the content of Si increased continuously as the Ca addition increased, while little $\mathrm{N}$ was detected in these inclusions.

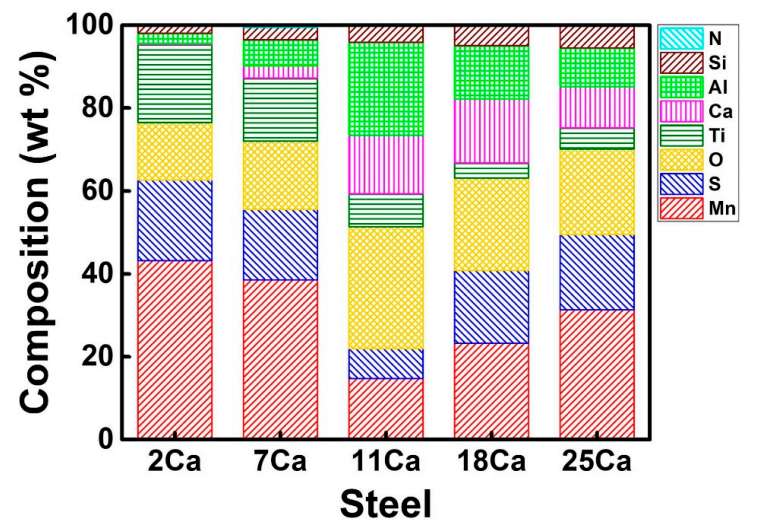

Figure 7. Average compositions of the non-metallic inclusions in the HAZs of the thick HSLA steel plates with different $\mathrm{Ca}$ concentrations after large heat input welding at $400 \mathrm{~kJ} \mathrm{~cm}^{-1}$, determined by SEM-EDS.

\subsection{Morphologies of Typical Inclusions}

The deoxidation of Ca changed the quantity, size, and composition of the non-metallic inclusions in the HAZs of these thick HSLA steel plates, as well as the morphology. Figure 8 shows the typical morphology of the pure MnS sulfide in the HAZs of the 2Ca and 7Ca steels, in which this pure inclusion had the largest quantity. Note that it formed a spherical or droplet morphology, corresponding well to the Type I morphology of sulfide in Sims' classification [23].

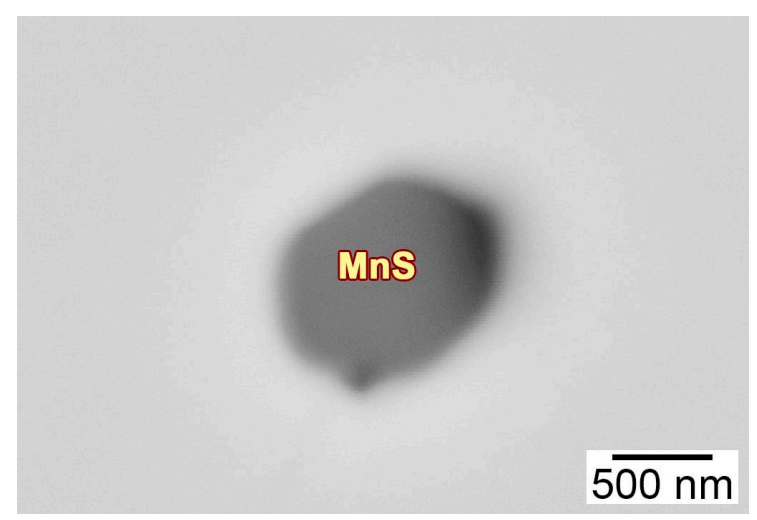

(a)

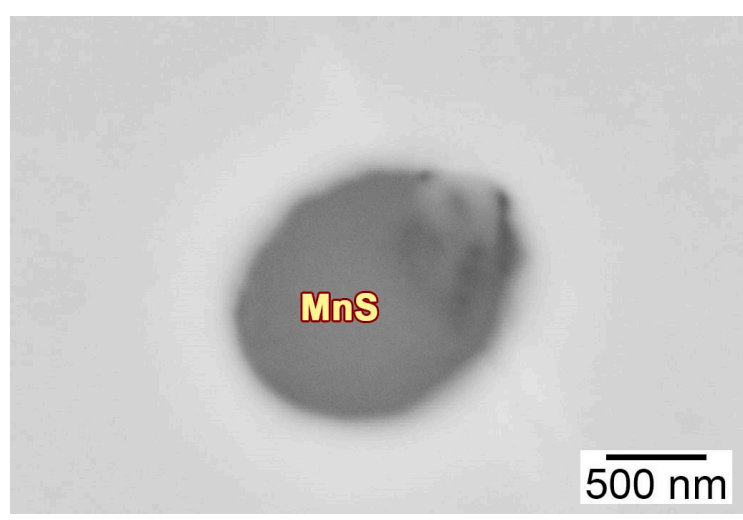

(b)

Figure 8. SEM-BSE images of the typical pure MnS sulfide in the HAZs of the thick HSLA steel plates (a) 2Ca and (b) 7Ca after large heat input welding at $400 \mathrm{~kJ} \mathrm{~cm}^{-1}$.

In addition to the pure MnS sulfide, the morphology and composition of the typical non-metallic inclusions in the HAZs of this steel system are shown in Figure 9. These displayed inclusions were all complex inclusions, comprising $\mathrm{Al}_{2} \mathrm{O}_{3}, \mathrm{CaO}, \mathrm{Ti}_{2} \mathrm{O}_{3}, \mathrm{MnS}$, and CaS. Figure 9(a1) shows the morphology of a typical $\mathrm{MnS}-\mathrm{Al}_{2} \mathrm{O}_{3}-\mathrm{Ti}_{2} \mathrm{O}_{3}$ complex oxysulfide, which had the second largest quantity in the $2 \mathrm{Ca}$ steel. It was composed of $\mathrm{MnS}$ and $\mathrm{Ti}_{2} \mathrm{O}_{3}$ two parts and some fine $\mathrm{Al}_{2} \mathrm{O}_{3}$ particles (Figure 9(b1)), revealing a fusiform morphology. The area of the $\mathrm{Ti}_{2} \mathrm{O}_{3}$ particle was relatively large, corresponding to the high content of Ti (Figure 7). 


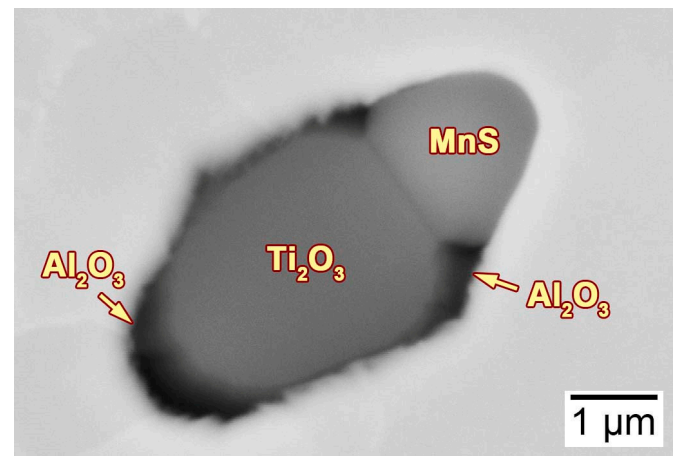

(a1)

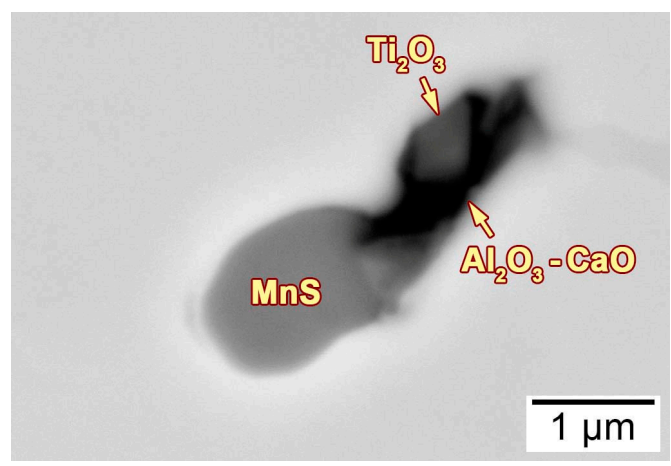

(a2)

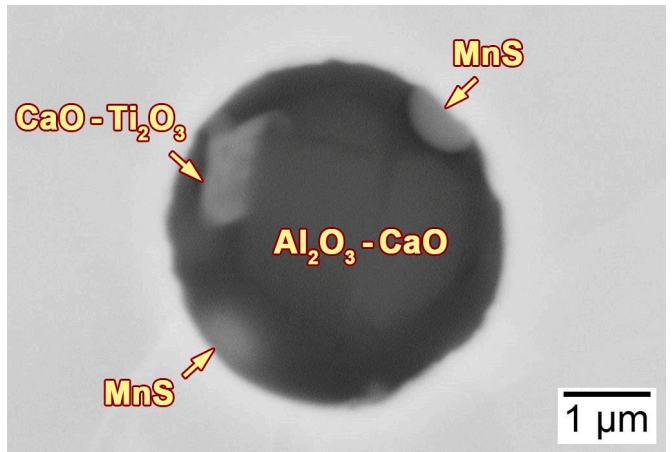

(a3)

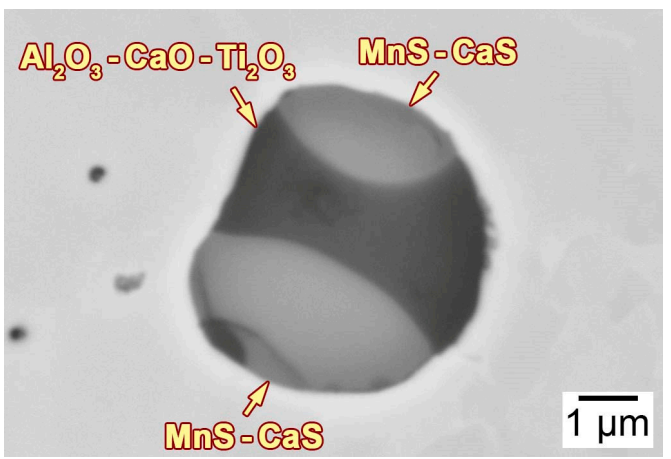

(a4)

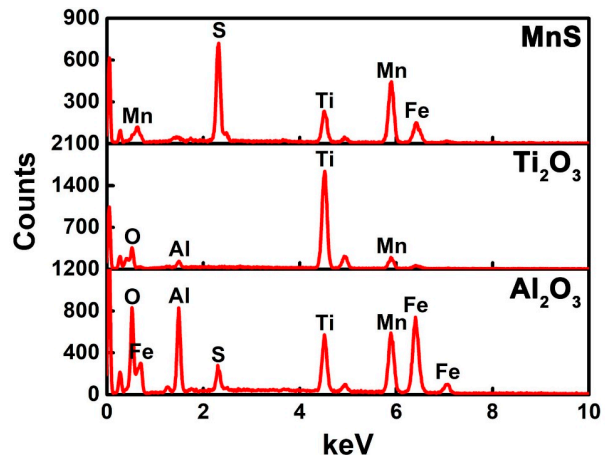

(b1)

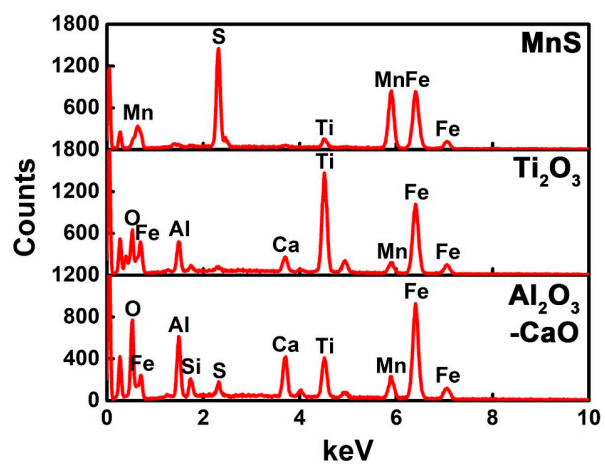

(b2)

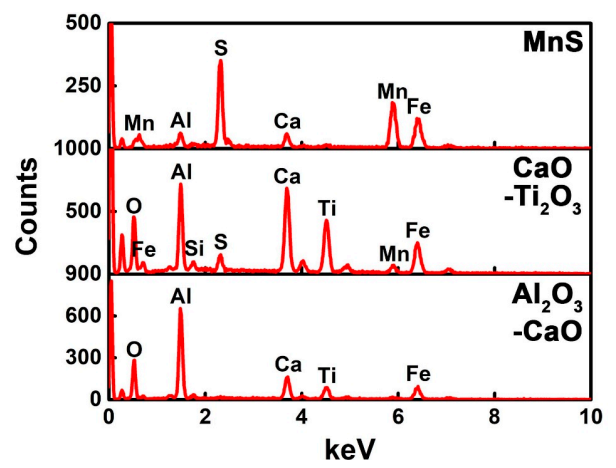

(b3)

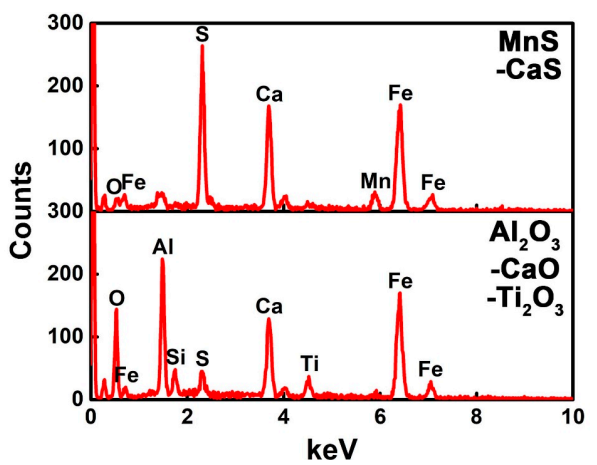

(b4)

Figure 9. Cont. 


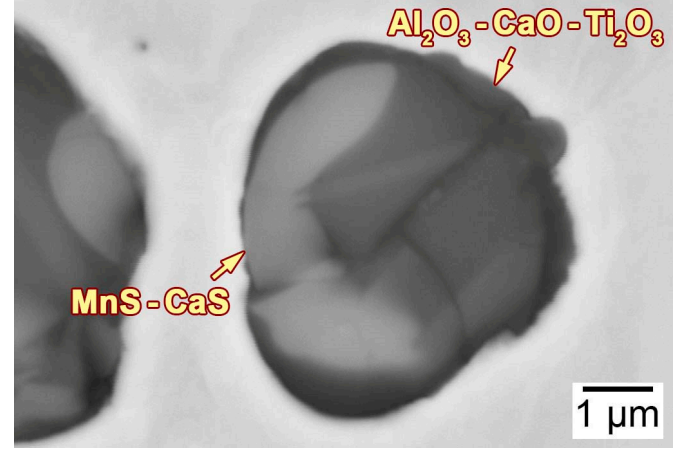

(a5)

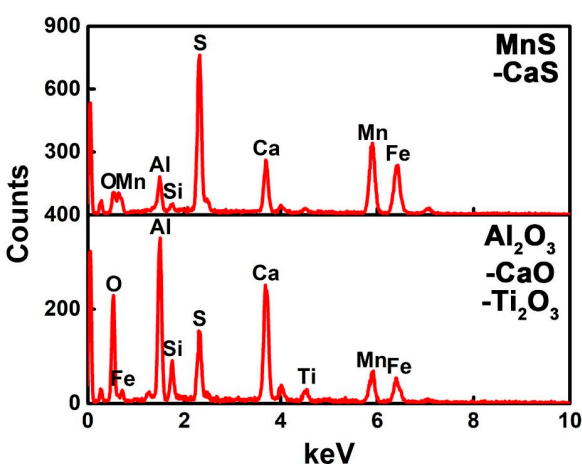

(b5)

Figure 9. (a1-a5) SEM-BSE images and corresponding (b1-b5) SEM-EDS spectra of the typical inclusions in the HAZs of the thick HSLA steel plates $(\mathbf{a} 1, \mathbf{b 1}) 2 \mathrm{Ca},(\mathbf{a} 2, \mathbf{b} 2) 7 \mathrm{Ca},(\mathbf{a} 3, \mathbf{b} 3) 11 \mathrm{Ca},(\mathbf{a} 4, \mathbf{b} 4) 18 \mathrm{Ca}$, and $(\mathbf{a} 5, \mathbf{b 5}) 25 \mathrm{Ca}$ after large heat input welding at $400 \mathrm{~kJ} \mathrm{~cm}^{-1}$.

Figure 9(a2) shows the morphology of a typical MnS- $\mathrm{Al}_{2} \mathrm{O}_{3}-\mathrm{CaO}-\mathrm{Ti}_{2} \mathrm{O}_{3}$ complex oxysulfide, a common inclusion in the 7Ca steel. It consisted of $\mathrm{MnS}, \mathrm{Ti}_{2} \mathrm{O}_{3}$, and $\mathrm{Al}_{2} \mathrm{O}_{3}-\mathrm{CaO}$ particles (Figure 9(b2)), and revealed a rod-like morphology. The $\mathrm{Ca}$ deoxidation had accelerated the formation of the $\mathrm{Al}_{2} \mathrm{O}_{3}-\mathrm{CaO}$ complex oxide and increased its area fraction, as well as decreasing the size of the $\mathrm{Ti}_{2} \mathrm{O}_{3}$ particle.

The morphology of the $\mathrm{MnS}-\mathrm{Al}_{2} \mathrm{O}_{3}-\mathrm{CaO}-\mathrm{Ti}_{2} \mathrm{O}_{3}$ complex inclusion with the largest quantity in the 11Ca steel is shown in Figure 9(a3). It was composed of a spherical $\mathrm{Al}_{2} \mathrm{O}_{3}-\mathrm{CaO}$ complex oxide, with the formation of some blocky $\mathrm{MnS}$ and $\mathrm{CaO}-\mathrm{Ti}_{2} \mathrm{O}_{3}$ particles on the surface (Figure 9(b3)). By comparison with that in the $2 \mathrm{Ca}$ and $7 \mathrm{Ca}$ steels, the size of the $\mathrm{MnS}$ particle was relatively small, and the formation of the pure $\mathrm{Ti}_{2} \mathrm{O}_{3}$ particle was eliminated.

Figure 9(a4) shows the morphology of a typical MnS-CaS- $\mathrm{Al}_{2} \mathrm{O}_{3}-\mathrm{CaO}-\mathrm{Ti}_{2} \mathrm{O}_{3}$ complex oxysulfide with the largest quantity in the $18 \mathrm{Ca}$ steel. The $\mathrm{Al}_{2} \mathrm{O}_{3}-\mathrm{CaO}-\mathrm{Ti}_{2} \mathrm{O}_{3}$ complex oxide was wrapped by a MnS-CaS complex sulfide (Figure 9(b4)), revealing a spherical and relatively large morphology. It is interesting that the formation of the $\mathrm{CaS}$ sulfide significantly increased the size and area fraction of the complex sulfide, and thus increased the content of $\mathrm{Mn}, \mathrm{Ca}$, and $\mathrm{S}$ (Figure 7). The morphology and composition of this $\mathrm{MnS}-\mathrm{CaS}-\mathrm{Al}_{2} \mathrm{O}_{3}-\mathrm{CaO}-\mathrm{Ti}_{2} \mathrm{O}_{3}$ complex oxysulfide in the 25Ca steel were similar to that in the 18Ca steel (Figure 9(a5,b5)).

\subsection{Microstructure and Impact Toughness at $-20^{\circ} \mathrm{C}$}

In order to evaluate the effect of the non-metallic inclusions on low temperature mechanical properties, the microstructure and impact toughness of the simulated HAZs in these thick HSLA steel plates with different $\mathrm{Ca}$ concentrations were examined. Figure 10 shows the microstructure of the simulated HAZs in the 2Ca and 25Ca steels after large heat input welding at $400 \mathrm{~kJ} \mathrm{~cm}^{-1}$. The microstructure of the $2 \mathrm{Ca}$ steel was composed of the IAF within the prior austenite grains, together with the coarse grain boundary ferrite (GBF) and ferrite side plate (FSP) on the grain boundary (Figure 10a). The microstructure of the 25Ca steel consisted of the IAF as well, but the size of the prior austenite grains was significantly reduced, as well as the elimination of the coarse FSP (Figure 10b). 


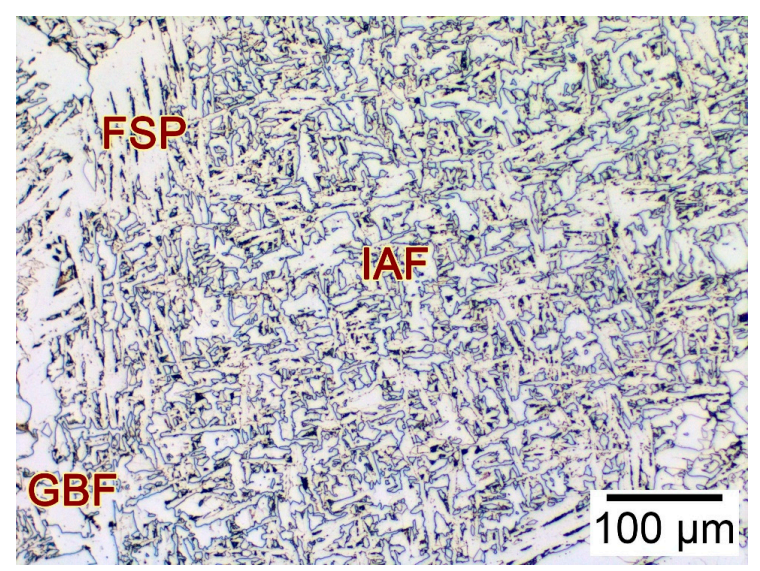

(a)

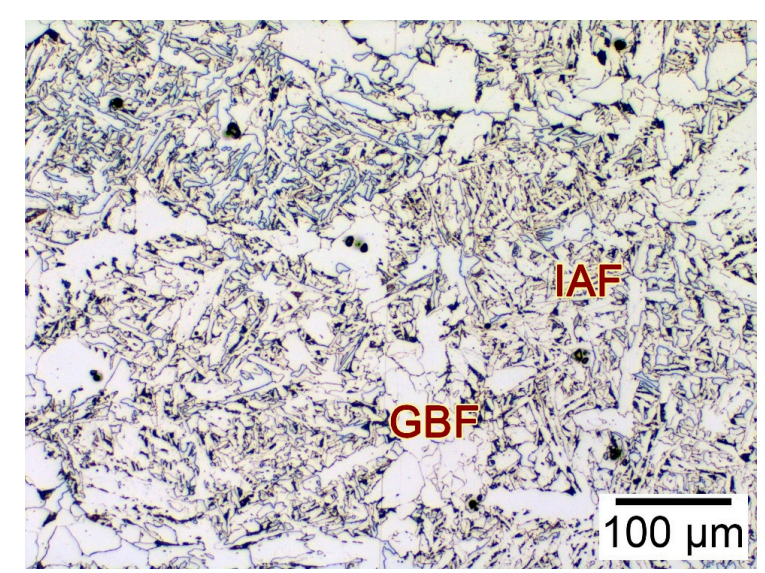

(b)

Figure 10. Microstructures of the simulated HAZs in the thick HSLA steel plates (a) 2Ca and (b) 25Ca at $-20{ }^{\circ} \mathrm{C}$ after large heat input welding at $400 \mathrm{~kJ} \mathrm{~cm}^{-1}$.

Figure 11 shows the impact toughness of the simulated HAZs in these thick HSLA steel plates with different $\mathrm{Ca}$ concentrations at $-20^{\circ} \mathrm{C}$ after large heat input welding at $400 \mathrm{~kJ} \mathrm{~cm}^{-1}$. The toughness of the HAZs was significantly improved as the Ca content increased, confirming the effectiveness of the Ca deoxidation in improving the welding property of these HSLA steels with ultra-high heat input.

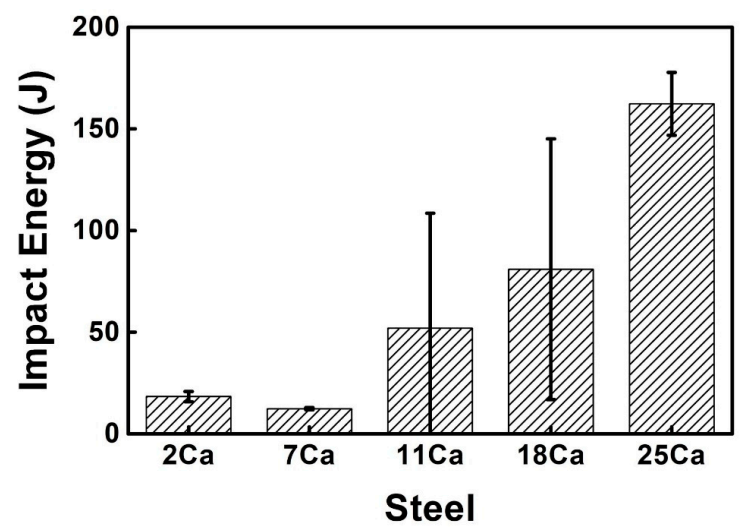

Figure 11. Impact toughness of the simulated HAZs in the thick HSLA steel plates with different Ca concentrations at $-20{ }^{\circ} \mathrm{C}$ after large heat input welding at $400 \mathrm{~kJ} \mathrm{~cm}^{-1}$.

\section{Discussion}

\subsection{Effect of Ca on Formation of Inclusions}

The statistics on the quantity, size, and composition of the non-metallic inclusions demonstrates that the Ca deoxidation significantly affects the formation behavior of the inclusions in the HAZs of the thick HSLA steel plates. As the Ca content increases, the number density of the pure MnS sulfide decreases, while that of the oxysulfide increases, in spite of the similar quantities of the total inclusions (Figures 3 and 5). This suggests that the addition of $\mathrm{Ca}$ induces an alteration in the formation mechanism of the non-metallic inclusions, from the pure MnS sulfide inclusion to the complex oxysulfide inclusion.

MnS sulfide generally forms after the liquid-solid solidification ends, and the related solubility products in liquid, $\gamma$-austenite, and $\delta / \alpha$-ferrite is described as follows: [20]

$$
\begin{gathered}
\lg [\% \mathrm{Mn}][\% \mathrm{~S}]_{\text {liquid }}=-6050 / \mathrm{T}+3.40 \\
\lg [\% \mathrm{Mn}][\% \mathrm{~S}]_{\gamma}=-11,200 / \mathrm{T}+5.10
\end{gathered}
$$




$$
\lg [\% \mathrm{Mn}][\%]_{\delta / \alpha}=-12,000 / \mathrm{T}+4.90 .
$$

The small solubility of the MnS sulfide in $\gamma$-austenite and $\delta / \alpha$-ferrite indicates that it preferentially precipitates from the solid region rather than the molten liquid region.

Besides the MnS sulfide, the CaS sulfide can also form in steels with relatively high Ca concentrations. The Gibbs free energy of the $\mathrm{CaO}$ oxide and the $\mathrm{CaS}$ sulfide formed in the molten liquid region at $1600{ }^{\circ} \mathrm{C}$ is described as follows: [24]

$$
\begin{aligned}
& {[\mathrm{Ca}]+[\mathrm{O}] \rightarrow \mathrm{CaO} \text { (solid) } } \Delta \mathrm{G}^{\Theta}=-326,000 \mathrm{~J} \mathrm{~mol}^{-1} \\
& {[\mathrm{Ca}]+[\mathrm{S}] \rightarrow \mathrm{CaS} \text { (solid) } \quad \Delta \mathrm{G}^{\Theta}=-319,000 \mathrm{~J} \mathrm{~mol}^{-1} . }
\end{aligned}
$$

The similar Gibbs free energies indicate that the thermal stability of the CaS sulfide is extremely high, just a bit lower than that of the $\mathrm{CaO}$ oxide. Therefore, the MnS sulfide generally forms in the solid region, while the $\mathrm{CaS}$ sulfide and the $\mathrm{CaO}$ oxide form in the molten liquid region, and this is confirmed by the thermodynamic calculations, as shown in Figure 1.

Previous studies have pointed out that the MnS sulfide can be classified into three types depending on its morphology: Type I (globular), Type II (rod-like), and Type III (angular), and the three types will be changed gradually as the Al content increases [23,25]. The pure MnS sulfide in the experimental HSLA steels forms the spherical morphology, a typical Type I sulfide (Figure 8), owing to the Al concentrations controlled below $100 \mathrm{ppm}$ (Table 1), the threshold for Type II sulfide alternation. This Type I sulfide forms through the metastable monotectic reaction below the solidus temperature:

$$
\operatorname{Liquid}_{(1)} \rightarrow \mathrm{Fe}_{(\text {solid })}+\operatorname{Liquid}_{(2)}
$$

in which the $\operatorname{Liquid}_{(2)}$ phase is enriched in MnS. Moreover, Oikawa et al. have highlighted that the molten oxide droplets can serve as nuclei for the separation of the liquid $\mathrm{MnS}$ and promote the monotectic reaction, leading to the spherical morphology [23]. Therefore, besides the pure MnS sulfide shown in Figure 8, the MnS part in Figure 9(a1,a2) can also be recognized as the Type I sulfide, together with the oxide nucleus $\left(\mathrm{Ti}_{2} \mathrm{O}_{3}\right.$ and $\mathrm{Al}_{2} \mathrm{O}_{3}-\mathrm{CaO}$ ) formed in the solid region.

Different form the molten oxide in the $2 \mathrm{Ca}$ and $7 \mathrm{Ca}$ steels, a thermally stable $3 \mathrm{CaO} \cdot \mathrm{Ti}_{2} \mathrm{O}_{3}$ complex oxide is predicted in the molten liquid region of the $11 \mathrm{Ca}, 18 \mathrm{Ca}$, and $25 \mathrm{Ca}$ steels, in advance of the $\mathrm{MnS}$ and CaS sulfide (Figure 1). Xiong et al. have recognized that the sulfide can precipitate on oxide at a specific habit plane and direction in an HSLA steel with Ti deoxidation [26]. Therefore, the MnS and CaS sulfide in these steels is presumed to heterogeneously nucleate on the surface of the prior solidified Ca-bearing oxide, resulting in the formation of the complex oxysulfide inclusion with a core (oxide) and shell (sulfide) structure (Figure 9(a3-a5)). The size of the MnS-CaS sulfide on the surface of the complex inclusion in the 18Ca and 25Ca steels is significantly larger than that in the 11Ca steel, primarily ascribing to its high formation position in the molten liquid region.

It is interesting that the Ca content affects the average size and composition of the total non-metallic inclusions in the HAZs of these thick steel plates as well (Figure 3, Figure 4, and Figure 7). The average size of the inclusions in the $18 \mathrm{Ca}$ and $25 \mathrm{Ca}$ steels is obviously larger than that in the $2 \mathrm{Ca}$, $7 \mathrm{Ca}$, and $11 \mathrm{Ca}$ steels (Figure 3), and this is primarily attributed to the increase in the size of the MnS-CaS- $-\mathrm{Al}_{2} \mathrm{O}_{3}-\mathrm{CaO}-\mathrm{Ti}_{2} \mathrm{O}_{3}$ oxysulfide, which forms in the molten liquid region according to the thermodynamic calculations (Figure 1). The formation of this coarse Ca-bearing oxysulfide is in good agreement with that reported by Wang et al. in an EH36 steel, though the morphologies are different [19]. In contrast to this coarse oxysulfide, the TiN nitride generally forms with a size smaller than $100 \mathrm{~nm}$, so it cannot be detected by SEM at relatively low magnifications, resulting in the extremely small number density, as shown in Figure 5.

Furthermore, the average compositions of $\mathrm{Mn}$ and $\mathrm{S}$ in these non-metallic inclusions decrease and then increase as the Ca content increases (Figure 7). The quantity statistics in Figure 5 suggests that the decrease in the $\mathrm{Mn}$ and S concentrations in the 2Ca and 7Ca steels is ascribed to the decline in the 
number density of the pure MnS and MnS-CaS sulfide, while the content increase in the 18Ca and 25Ca steels is owed to the growth of the MnS-CaS sulfide on the oxysulfide surface. As regards the 11Ca steel, the lowest number density of the pure MnS and MnS-CaS sulfide gives rise to the minimum concentrations of Mn and S.

The content of Ti in these non-metallic inclusions decreases continuously as the Ca content increases, due to the change from Ti deoxidation to Ca deoxidation. The Ti content is presumed to form the nitride that can affect the microstructure of the HAZs, particularly the size of the prior austenite grains. Therefore, more efforts will be paid to investigate the Ca effect on the formation behavior of TiN nitrides in our future research.

\subsection{Effective Inclusions in Enhancing the HAZ Toughness}

The $\mathrm{Ca}$ addition can change the formation of the non-metallic inclusions and consequently affect the microstructure and toughness of the HAZs in these thick HSLA steel plates after large heat input welding at $400 \mathrm{~kJ} \mathrm{~cm}^{-1}$. As the Ca concentrations increase, these inclusions not only improve the formation of IAFs, but also decrease the size of the prior austenite grains, leading to the increase in the $\mathrm{HAZ}$ toughness at $-20^{\circ} \mathrm{C}$ (Figures 10 and 11). Therefore, the effective inclusions are those that can improve the microstructural refinement in the HAZs of the thick HSLA steel plates after large heat input welding.

Plenty of studies have highlighted that the complex inclusions composed of oxide-nitride-MnS, oxide-MnS, and nitride-MnS, as well as Ti-bearing oxide, are positive in inducing IAFs $[9,15,27,28]$. Ishikawa et al. have pointed that the pure MnS sulfide is unlikely to act as a direct nucleation site for IAFs [29]. It is interesting that the inter-locking IAF is formed in the HAZ of all the thick HSLA steel plates, regardless of the Ca concentrations. This is thus ascribed to the effective Ti-bearing oxides, which are formed by the Ti and Ca combined deoxidation (Table 1 and Figure 5). However, the brittle FSP is formed on the grain boundary of the 2Ca and 7Ca steels, in which the ineffective pure MnS sulfide has the dominant quantities. In contrast, the quantity of the pure $\mathrm{MnS}$ sulfide is reduced in the $18 \mathrm{Ca}$ and $25 \mathrm{Ca}$ steels, while the MnS-CaS- $\mathrm{Al}_{2} \mathrm{O}_{3}-\mathrm{CaO}-\mathrm{Ti}_{2} \mathrm{O}_{3}$ oxysulfide with a core (oxide) and shell (sulfide) structure can form the Mn-depleted zone (MDZ) and thus completely eliminate the FSP by forming the strong IAF.

Moreover, Zhou et al. have recognized that the fine Ti-Zr complex oxide can effectively retard the grain boundary migration during the welding thermal cycle, resulting in fine grains [11]. Wu et al. have pointed that the nanoscale TiN nitride is extremely effective in restricting the growth of the prior austenite grains during the large input welding [30]. This indicates that the effective inclusions on the refinement of grain size should be fine and thermally stable, preferentially those formed in the molten liquid. Therefore, the MnS sulfide that precipitated at relatively low temperatures is not able to pin the grain boundary, different from the MnS-CaS- $\mathrm{Al}_{2} \mathrm{O}_{3}-\mathrm{CaO}-\mathrm{Ti}_{2} \mathrm{O}_{3}$ oxysulfide. Comparing the distribution of the inclusions in the 2Ca and 25Ca steels (Figure 5), it is recognized that the prior grain size of the $25 \mathrm{Ca}$ is decreased by forming these complex thermal-stable oxysulfides.

Therefore, a relatively high Ca content is demanded for the design of these thick HSLA steel plates, in order to form the effective oxysulfide with a core-shell structure, giving rise to the refinement of the HAZ microstructure and the enhancement of the HAZ toughness.

\section{Conclusions}

The formation behavior of the non-metallic inclusions in the HAZs of a series of thick HSLA steel plates after large heat input welding at $400 \mathrm{~kJ} \mathrm{~cm}^{-1}$ was investigated, and the effect of Ca content on the quantity, size, morphology, and composition of the inclusions are explained. Conclusions are addressed as follows.

1. The Ca addition decreases the number density of the pure MnS sulfide, and increases that of the complex oxysulfide. It also increases the size of the complex oxysulfide, thereby increasing the 
average size of the total inclusions. The average compositions of $\mathrm{Mn}$ and $\mathrm{S}$ in these non-metallic inclusions decrease and then increase as the Ca content increases, but the Ti composition decreases continuously.

2. The pure MnS sulfide forms the spherical morphology through the metastable monotectic reaction below the solidus temperature, due to its small solubility in $\gamma$-austenite and $\delta / \alpha$-ferrite. The Ca addition increased the formation temperature of the $\mathrm{CaS}$ sulfide and $\mathrm{CaO}$ oxide, leading to the formation of the complex oxysulfide with the core (oxide) and shell (sulfide) structure in the molten liquid.

3. The HAZ toughness of these thick HSLA steel plates is increased as the Ca concentrations increase, primarily owing to the positive effect of the inclusions on the refinement of the HAZ microstructure. The complex oxysulfide with the core-shell structure can form the MDZ and thus prevent the formation of the brittle FSP by the strong IAF. These fine complex oxysulfide can also retard the grain boundary migration and ultimately decrease the size of the prior austenite grains.

Author Contributions: Y.Z. and J.Y. conceived and designed this research. Y.Z. performed the experiments and thermodynamic calculations. Y.Z. analyzed the experimental results and wrote this manuscript. L.X., Y.Q., G.C., M.Y., and J.D. provided useful discussions and suggestions. J.Y. contributed correction of English and proofreading.

Funding: This work was financially supported by the National Natural Science Foundation of China (Grant No. U1960202 and No. 51801118) and the Project funded by China Postdoctoral Science Foundation (Grant No. 2017M621430).

Acknowledgments: The authors are grateful to X.F. Jiang and R.Z. Wang for the assistance in steelmaking and TMCP treatment.

Conflicts of Interest: The authors declare no conflict of interest.

\section{References}

1. Shirahata, H.; Okawa, T.; Nakashima, K.; Yanagita, K.; Inoue, T.; Inami, A.; Ishida, K.; Minagawa, M.; Funatsu, Y. YP $460 \mathrm{~N} / \mathrm{mm}^{2}$ class heavy thick plate with excellent brittle crack arrestability for mega container ships. Nippon Steel E Sumitomo Metal Tech. Rep. 2015, pp. 25-29. Available online: https: //www.nipponsteel.com/en/tech/report/nssmc/pdf/110-05.pdf (accessed on 1 March 2019).

2. Minagawa, M.; Ishida, K.; Funatsu, Y.; Imai, S. $390 \mathrm{MPa}$ yield strength steel plate for large heat-input welding for large container ships. Nippon Steel Tech. Rep. 2004, pp. 7-10. Available online: https: //www.nipponsteel.com/en/tech/report/nsc/pdf/n9003.pdf (accessed on 1 March 2019).

3. Sun, J.C.; Zou, X.D.; Matsuura, H.; Wang, C. Effect of heat input on inclusion evolution behavior in heat-affected zone of EH36 shipbuilding steel. JOM 2018, 70, 946-950. [CrossRef]

4. Shi, Z.R.; Yang, C.F.; Wang, R.Z.; Su, H.; Chai, F.; Chu, J.F.; Wang, Q.F. Effect of nitrogen on the microstructures and mechanical properties in simulated CGHAZ of vanadium microalloyed steel varied with different heat inputs. Mater. Sci. Eng. A 2016, 649, 270-281. [CrossRef]

5. Cao, R.; Li, J.; Liu, D.S.; Ma, J.Y.; Chen, J.H. Micromechanism of decrease of impact toughness in coarse-grain heat-affected zone of HSLA steel with increasing welding heat input. Metall. Mater. Trans. A 2015, 46, 2999-3014. [CrossRef]

6. Lou, H.N.; Wang, C.; Wang, B.X.; Wang, Z.D.; Li, Y.Q.; Chen, Z.G. Inclusion evolution behavior of Ti-Mg oxide metallurgy steel and its effect on a high heat input welding HAZ. Metals 2018, 8, 534. [CrossRef]

7. Kanazawa, S.; Nakashima, A.; Okamoto, K.; Kanaya, K. Improved toughness of weld fussion zone by fine TiN particles and development of a steel for large heat input welding. Tetsu-to-Hagane 1975, 61, 2589-2603. [CrossRef]

8. Kasamatsu, Y.; Takashima, S.; Hosoya, T. Effect of titanium and nitrogen on toughness of heat-affected zone of steel plate with tensile strength of $50 \mathrm{~kg} / \mathrm{mm}^{2}$ in high heat input welding. Tetsu-to-Hagane 1979, 65, 1232-1241. [CrossRef]

9. Yamamoto, K.; Hasegawa, T.; Takamura, J.-I. Effect of boron on intra-granular ferrite formation in Ti-oxide bearing steels. ISIJ Int. 1996, 36, 80-86. [CrossRef] 
10. Xu, L.Y.; Yang, J.; Wang, R.Z. Influence of Al content on the inclusion-microstructure relationship in the heat-affected zone of a steel plate with Mg deoxidation after high-heat-input welding. Metals 2018, 8, 1027. [CrossRef]

11. Zhou, B.W.; Li, G.Q.; Wan, X.L.; Li, Y.; Wu, K.M. In-situ observation of grain refinement in the simulated heat-affected zone of high-strength low-alloy steel by Zr-Ti combined deoxidation. Met. Mater-Int. 2016, 22, 267-275. [CrossRef]

12. Li, Y.; Wan, X.L.; Cheng, L.; Wu, K.M. First-principles calculation of the interaction of $\mathrm{Mn}$ with $\mathrm{ZrO}_{2}$ and its effect on the formation of ferrite in high-strength low-alloy steels. Scr. Mater. 2014, 75, 78-81. [CrossRef]

13. Suzuki, S.; Ichimiya, K.; Akita, T. High tensile strength steel plates with excellent HAZ toughness for shipbuilding. JFE Tech. Rep. 2005, 5, 24-29. Available online: https://www.jfe-steel.co.jp/en/research/report/ 005/pdf/005-05.pdf (accessed on 1 March 2019).

14. Xu, L.Y.; Yang, J.; Wang, R.Z.; Wang, Y.N.; Wang, W.L. Effect of Mg content on the microstructure and toughness of heat-affected zone of steel plate after high heat input welding. Metall. Mater. Trans. A 2016, 47, 3354-3364. [CrossRef]

15. Xu, L.Y.; Yang, J.; Wang, R.Z.; Wang, W.L.; Wang, Y.N. Effect of Mg addition on formation of intragranular acicular ferrite in heat-affected zone of steel plate after high-heat-input welding. J. Iron Steel Res. Int. 2018, 25, 433-441. [CrossRef]

16. Wang, C.; Misra, R.D.K.; Shi, M.H.; Zhang, P.Y.; Wang, Z.D.; Zhu, F.X.; Wang, G.D. Transformation behavior of a Ti-Zr deoxidized steel: Microstructure and toughness of simulated coarse grain heat affected zone. Mater. Sci. Eng. A 2014, 594, 218-228. [CrossRef]

17. Xu, L.Y.; Yang, J.; Wang, R.Z.; Wang, W.L.; Ren, Z.M. Effect of welding heat input on microstructure and toughness of heated-affected zone in steel plate with Mg deoxidation. Steel Res. Int. 2017, 88, 1700157. [CrossRef]

18. Yang, J.; Xu, L.Y.; Zhu, K.; Wang, R.Z.; Zhou, L.J.; Wang, W.L. Improvement of HAZ toughness of steel plate for high heat input welding by inclusion control with Mg deoxidation. Steel Res. Int. 2015, 86, 619-625. [CrossRef]

19. Wang, Q.Y.; Zou, X.D.; Matsuura, H.; Wang, C. Evolution of inclusions during the $1473 \mathrm{~K}\left(1200^{\circ} \mathrm{C}\right)$ heating process of EH36 shipbuilding steel. Metall. Mater. Trans. B 2018, 49, 18-22. [CrossRef]

20. Zhang, L.F. Non-Metallic Inclusions in Steel: Fundamentals; Metallurgical Industry Press: Beijing, China, 2019; pp. 196-198.

21. Kato, T.; Sato, S.; Ohta, H.; Shiwaku, T. Effects of Ca addition on formation behavior of TiN particles and HAZ toughness in large heat input welding. Kobelco Technol. Rev. 2011, 76-79. Available online: https://www.kobelco.co.jp/english/ktr/pdf/ktr_30/076-079.pdf (accessed on 1 March 2019).

22. Nakashima, K.; Hase, K.; Eto, T. Development of shipbuilding steel plate with superior low temperature toughness for large heat input welding. JFE Tech. Rep. 2015, 8-13. Available online: https://www.jfe-steel.co. jp/en/research/report/020/pdf/020-03.pdf (accessed on 1 March 2019).

23. Oikawa, K.; Ohtani, H.; Ishida, K.; Nishizawa, T. The control of the morphology of MnS inclusions in steel during solidification. ISIJ Int. 1995, 35, 402-408. [CrossRef]

24. Li, S.S.; Ren, Y.; Zhang, L.F.; Yang, W. Study on $\mathrm{CaO}$ and $\mathrm{CaS}$ inclusions in pipeline steel during refining process. J. Univ. Sci. Technol. Beijing 2014, 36, 168-172.

25. Lichy, E.J.; Duderstadt, G.C.; Samways, N.L. Control of sulfide shape in low carbon Al-killed steel. JOM 1965, 17, 769-775. [CrossRef]

26. Xiong, Z.H.; Liu, S.L.; Wang, X.M.; Shang, C.J.; Misra, R.D.K. Relationship between crystallographic structure of the $\mathrm{Ti}_{2} \mathrm{O}_{3} / \mathrm{MnS}$ complex inclusion and microstructure in the heat-affected zone (HAZ) in steel processed by oxide metallurgy route and impact toughness. Mater. Charact. 2015, 106, 232-239. [CrossRef]

27. Furuhara, T.; Shinyoshi, T.; Miyamoto, G.; Yamaguchi, J.; Sugita, N.; Kimura, N.; Takemura, N.; Maki, T. Multiphase crystallography in the nucleation of intragranular ferrite on $\mathrm{MnS}+\mathrm{V}(\mathrm{C}, \mathrm{N})$ complex precipitate in austenite. ISIJ Int. 2003, 43, 2028-2037. [CrossRef]

28. Hou, Y.H.; Zheng, W.; Wu, Z.H.; Li, G.Q.; Moelans, N.; Guo, M.X.; Khan, B.S. Study of Mn absorption by complex oxide inclusions in Al-Ti-Mg killed steels. Acta Mater. 2016, 118, 8-16. [CrossRef] 
29. Ishikawa, F.; Takahashi, T.; Ochi, T. Intragranular ferrite nucleation in medium-carbon vanadium steels. Metall. Mater. Trans. A 1994, 25, 929-936. [CrossRef]

30. Wan, X.; Zhou, B.; Nune, K.C.; Li, Y.; Wu, K.; Li, G. In-situ microscopy study of grain refinement in the simulated heat-affected zone of high-strength low-alloy steel by TiN particle. Sci. Technol. Weld. Join. 2017, 22, 343-352. [CrossRef] 